\title{
Non-performing Loan and its Effects on Banking Stability: Evidence from National and International Licensed Banks in Nigeria
}

Ngozi V. Atoi $^{1}$

This study examines Non-Performing Loan (NPL) and its effects on the stability of Nigerian banks with national and international operational licenses from 2014:Q2 to 2017:Q2. A "restricted" dynamic GMM is employed to estimate the macroeconomic and bank specific drivers of NPL for each licensed category. Z-Score is constructed to proxy banking stability, and its response to shocks NPLs is examined in a panel vector autoregressive framework. The results reveal that drivers of NPLs vary across the two categories of banks, but, weighted average lending rate is a vital macroeconomic driver of NPLs for both. The results also confirm the moral hazard hypothesis and riskreturn tradeoff of efficient market theory. Furthermore, international banks withstand NPLs shocks in the long run, despite temporary flux in the short horizon, while the stability of national banks is susceptible to NPLs shocks in the long run. The study recommends that weighted average lending rate, anchored on monetary policy rate should be the focus of banks' regulators when addressing issues of NPLs. Again, strategies for mitigating short run impacts of NPLs on the stability of international licensed banks should be incorporated in the off-site regulatory framework to ensure banking stability.

Keywords: Banking System Stability, Non-performing Loan, Panel Generalized Methods of Moments, Panel Vector Autoregressive .

JEL Classification: G210, C330, C360.

DOI: 10.33429/Cjas.09218.3/6

\subsection{Introduction}

Nonperforming loans (NPLs) and Banking system stability nexus continues to gain more research attention, especially after the 2008/2009 global financial crisis (GFC) that led to credit crisis in most economies. Eonomies that were running on

\footnotetext{
${ }^{1}$ Department of Statistics, Central Bank of Nigeria, Abuja, Nigeria; nvatoi@cbn.gov.ng; atoinv@gmail.com.

The views expressed in this paper are solely those of the author and do not necessarily represent those of the Central Bank of Nigeria
} 
Non-performing Loan and its Effects on Banking Stability: Evidence from National and International Licensed Banks in Nigeria

a booming banking sector during pre-crisis period were forced to a sudden credit growth halt in 2008 (IMF, 2012). Measures were adopted to mitigate the effects of NPLs on Banking stability in the wake of the GFC.

In Nigeria, apart from establishing a special purpose vehicle to manage the buildup of NPLs, commercial banking operations were streamlined by the Central Bank of Nigeria (CBN) to provide clarity on the conduct of commercial banking activities with respect to geographical coverage, among others. The policy ushered in commercial banks with international, national and regional operational licenses. ${ }^{2}$ As the names imply, a commercial bank with international license is allowed to maintain offshore banking operation in the jurisdiction of its choice within and across the national boundaries; a national licensed bank carries out banking operations within national boundaries while regional licensed banks operate within specified geographical locations in Nigeria. The repositioning ensured that banks' operational coverage is commensurate to their paid-up share capital. These measures put in place to address the ailing capital structure attributable to NPLs impacted the banking system positively up to end 2014 .

In recent times, NPLs has been trending and becoming a cause of concern for banks' stability in the face of reeling economic downturn. In CBN (2015), the banking industry: large, medium and small bank groups showed vulnerability to the most severe shock of 200 per cent rise in NPLs, but none of the groups could sustain the impact of the same magnitude of shocks in December 2016 as their post-shock capital adequacy ratios fell below the 10 per cent minimum prudential requirement (CBN, 2016). Oftentimes, the same prudential tools such as liquidity ratio, loans to deposit ratio, large exposure and reserve requirements have been applied to address issues of NPLs of banks, irrespective of size. Two questions are relevant here: first, do NPLs of all categories of operational licenses respond to the same drivers?; second, are the responses of banking stability to NPLs shocks

\footnotetext{
${ }^{2}$ The classification of banks into international, national and regional is analogous to bank size in most literature and the source document of this classification can be found in the CBN website through the URL: https://www.cbn.gov.ng/out/2010/circulars/bsd/commercial \%20banking\%20licensing\%20regulations\%20-\%20final\%20released.pdf
} 
across these bank categories the same? The efficacy of the prudential tools may be unrealized if not administered in line with a firm understanding of specific factors of NPLs.

Some studies have argued that NPLs and its impact on banking stability cannot be the same across different categories of banks due to varied levels of market discipline, risk management strategies, regulatory and supervisory measures, and sources of capital (Detragiache and Gupta (2006), Martinez-Miera and Repullo (2010) and Bertay et al. (2013)).

Most empirical studies on NPLs and banking stability nexus in Nigeria have neglected the idiosyncratic or heterogeneity characteristics of these banks with respect to operational coverage (Kanu and Himliton (2014), Akinlo and Mofoluwaso (2014), Kolapo et al. (2012), Onwe (2015) and Mensah and Adjei (2015)). Thus, the two fundamental areas our study is contributing to existing literature in Nigeria are: (i) accounting for geographical coverage of banking activities and (ii) employing more robust analytical methods.

The objective of this study is to estimate the factors influencing NPLs and also investigate the feedback effect of shocks to NPLs on stability of banks with international and national authorization. To achieve these objectives, first, macroeconomic and bank specific predictors of NPLs for each banking category are estimated using a restricted dynamic GMM one step technique. Second, we extract the response of banks stability (Z-score) to NPLs shocks in a panel vector autoregressive framework. The regional banks are not considered in this study due to their marginal size and limited years of existence.

The outcome of this study will help portfolio investment managers to minimize risk and optimize returns; and also enhance regulatory/prudential toolkits of the monetary authority in providing: (i) specific supervisory policies for addressing the issues of NPLs, and (ii) policy options for mitigating impact of NPLs on the banking system. In addition, this study seeks to bridge the identified gap in literature. The study covers the period 2014:Q2 to 2017:Q2, when the selected banks 
Non-performing Loan and its Effects on Banking Stability: Evidence from National and International Licensed Banks in Nigeria

had consistent bank specific data with the same uniform reporting year.

The remainder of the paper is structured as follows: section two examines some stylized facts in the Nigerian Banking System. The conceptual framework, theoretical and empirical literature are examined in section three, while section four focuses on methodology. Section five deals with data analysis and interpretation of results; and finally, section six presents the conclusion and policy recommendations.

\subsection{Stylised Facts on the Nigeria Banking System}

Over the years, the Nigerian banking system has metamorphosed in the area of ownership structure, operational coverage and number of institutions. Prior to 2005 banking system consolidation in Nigeria, eighty nine banks existed under a universal banking system - a framework that placed no restrictions on banks' share capital investments in other financial service sectors. This led to the proliferation of other financial institutions having banks as minority or majority shareholders and this created supervisory bottlenecks for the regulating institution due to subsidiaries' interconnectedness. Despite these investments and considering the population of Nigeria, huge capital market and the overall economic activities, the banking system was rated very marginal relative to its potential (CBN, 2009).

The ailing condition of the banks led to the consolidation of the sector in 2005 through mergers and acquisitions with the view to enhancing its efficiency, size, and developmental roles. In the process, bank's minimum capital was raised and the number of banks reduced to twenty five, and this further reduced to twenty four through market-induced merger and acquisition. The exercise, coupled with huge inflow from oil receipts created excess liquidity in the system, a level higher than the economy's absorptive capacity. This led to a further investment in oil and gas sector equities, thereby creating significant boom in the capital market. With the arrival of 2008/2009 GFC, the oil price, as well as returns on investment in that sector plummeted significantly and was accompanied by unprecedented capital outflow thus throwing the banking system into a high credit risk situation. The asset quality of Nigerian banks dropped significantly as NPLs skyrocketed 
with attendant economic consequences.

To avoid a systemic failure and revitalize the system, Asset Management Corporation of Nigeria (AMCON) - a special purpose vehicle was established in 2011 to take over toxic assets through issuance of bonds. Thereafter, the regulatory authority also restrained banks from granting further credit to potential borrowers with (i) un-serviced facility exceeding a certain amount or (ii) any amount of delinquent facility that was taken over by AMCON. To further enhance the resilience of the banking system, commercial banks which constitute the major part of the banking system, were further categorized into regional, national and international. Each category has specified operational coverage and minimum level of capital requirement in terms of capital base and adequacy ratios (see Table 1).

Table 1: Licensing Requirements of Commercial Bank Categories in Nigeria

\begin{tabular}{|c|c|c|c|c|c|}
\hline Bank License & Operational Coverage & $\begin{array}{c}\text { Capital } \\
\text { Adequacy } \\
\text { Ratio }\end{array}$ & $\begin{array}{c}\text { Commercial } \\
\text { Banks }\end{array}$ & $\begin{array}{c}\text { Merchant } \\
\text { Banks }\end{array}$ & Capital Base \\
\hline Regional & $\begin{array}{l}\text { (i) } 6 \text { to } 12 \text { contiguous } \\
\text { States; } \\
\text { (ii) Not more than two (2) } \\
\text { Geo-Political Zones; } \\
\text { (iii) Federal Capital } \\
\text { Territory }\end{array}$ & $10 \%$ & 2 & & N10 Billion \\
\hline National & $\begin{array}{l}\text { (i) Every State of the } \\
\text { Federation }\end{array}$ & $10 \%$ & 9 & 4 & N15 Billion \\
\hline International & $\begin{array}{l}\text { (i) Every State of the } \\
\text { Federation } \\
\text { (ii) Offshore, subject to } \\
\text { compliance with host } \\
\text { country regulatory } \\
\text { requirements }\end{array}$ & $15 \%$ & 10 & & N50 Billion \\
\hline
\end{tabular}

However, the fall in international oil price coupled with the Nigeria Naira to US Dollar (N/US\$) exchange rate volatility undermined these measures as NPLs continued trending upward to 2017:Q1. It therefore becomes imperative to examine NPLs and its impact on the banking system stability with particular reference to new classification of commercial banks in Nigeria with a view to proffering appropriate specific policy measures for addressing issues of NPLs in the various banks' categories. 
Non-performing Loan and its Effects on Banking Stability: Evidence from National and International Licensed Banks in Nigeria

\subsection{Literature Review}

\subsection{Conceptual Framework}

Banking system is a combination of financial institutions responsible for safekeeping and lending of money and the provision of other financial services to the populace (CBN, 2016). Technically, deposit takers whose liabilities are included in the national definition of broad money are very significant component of the banking system. In most emerging economies where the non-bank financial institutions are still nascent, the deposit takers component of the banking system is usually huge. Hence, shock on asset side of a group of banks, through rising amount of NPLs in the credit portfolio could spillover and affect the stability of the system. A good measure of banking stability is essential for addressing issues of instability in the system.

In most academic literature, stability of banks has been measured under CAMELS framework by using individual indicator like return on assets (ROA) and return on equity (ROE) (see Kolapo et al. (2012), Warue (2013), Mensah and Adjei (2015)). Return on assets measures efficiency of deposit takers in the use of assets in generating earnings. ROA reveals how debt drives returns, the same way ROE shows the extent of equity investment effectiveness. Banking system stability may not be adequately captured with a single indicator because bank's capital adequacy ratio, for instance may not guarantee stability. Gadanecz and Jayaram (2009) note that central banks like Czech National Bank (CNB), Hong Kong Monetary Authority (HKMA), Central Bank of Turkey (CBT) and Swiss National Bank (SNB) are now measuring banking stability using composite indices. Hence, a Z-score computed with ROA and ROE could serve as a proxy for banking system stability.

Financial stability index has been found useful due to its capabilities; it mirrors the country's financial structure (ECB, 2007), accounts for financial innovations (Boudebbous and Chichti, 2013), allows policy-makers to monitor the development of stressful situations and considers the state of banks' behaviour on individual basis (Raluca and Dumitru, 2014). Sere-Ejembi et al. (2014) employ conference board methodology, while Raluca and Dumitru (2014) apply Z-score that was first 
proposed by Altman (2000) and developed by Mercieca et al. (2007) to construct banking system stability index. Schaeck (2007) argues that the main advantage of Z-score is computational simplicity for financial institutions or corporations. Extant theories have established a connection between NPLs and banking stability, thus, it is also imperative to understand the fundamentals of NPLs.

The concept of NPLs has been expressed by different authors in the literature. One common feature of NPL is the period over which the principal and interest remain unpaid and un-serviced before a loan is classified as non-performing. Caprio and Klingebiel (1990) described NPLs as loans that do not generate income over a sustained period of at least three months. In the same vain, Alton and Hazen (2001) expressed NPLs as loans that are 90 days or more past due or no longer accruing interest. The IMF Financial Soundness Indicators Compilation Guide of 2006 recommends that loans are classified as non-performing when payment of principal and interest are past due by three months or more or when interest payments equalling three months interest or more have been capitalized, refinanced or rolled over. One interesting argument put forward by the IMF Guide is that a loan can also be classified as non-performing when the debtor files for bankruptcy. In Nigeria, NPLs is classified into substandard, doubtful, very doubtful and lost.

\subsection{Theoretical Literature}

The theory of NPLs as it relates to stability of banks rests on three pillars: (i) information asymmetry, (ii) adverse selection and (iii) moral hazard theories. They provide useful information on the traditional causes of loan default that translates to banking system instability. Information asymmetry theory was first applied by Akerlof (1970). The theory states that it may be complex to differentiate between good and bad borrowers and this may lead to adverse selection and moral hazard problems. In line with the theory, Cottarelli et al. (2005) and Kraft and Jankov (2005) show the role of loan growth in bank risk-taking and resulting instability. The theory also relates to contagious withdrawals when depositors are imperfectly informed about the type of shocks hitting banks and about interbank exposures (De Bandt and Hartmann, 2000). 
Non-performing Loan and its Effects on Banking Stability: Evidence from National and International Licensed Banks in Nigeria

Propounded by Akerlof (1970) and later expanded by Rothschild and Stiglitz (1976), the adverse selection theory describes the situation where the probability of loan default increases with rising interest rate and the quality of borrowers worsens as the cost of borrowing rises (Musara and Olawale, 2012). The theory is founded on the assumption that banks are not certain in selecting credit-worthy borrowers from a pool of loan seekers with different credit risk exposures ex-ante. Thus, financial intermediaries are more likely to lend to high-risk borrowers who are not concerned about the harsh lending conditions and are prone to loan default (Ezeoha, 2011). Pagano and Jappelli (1993) argue that information sharing reduces adverse selection problems by enhancing information on loan applicants. More so, Padilla and Pagano (2000) document that if banks exchange credit information on defaults, then borrowers are encouraged to apply more energy in their projects knowing fully well that loan default carries the penalty of higher interest rates or no future access to credit facility.

Before Stiglitz and Weiss (1983) and Stiglitz (1990) proposed moral hazard model for credit market, Arrow (1963) documents that the phenomenon of using private information to benefit from an incomplete contract in the presence of information asymmetry is known as moral hazard. Musara and Olawale (2012) also noted that moral hazard exist where the borrower of bank credit takes action that adversely affects the returns to the lender. Gorton and Pennacchi (1995) posit that a bank that makes and sells loans is subject to a moral hazard problem with respect to screening borrowers. The theory is based on the assumption that the likelihood of borrowers engaging in activities that will guarantee repayment of bank credit extended to them cannot be determined ex-post by banks.

\subsection{Empirical Literature}

Previous empirical findings provide evidence of varying NPLs drivers across bank categories in emerging and advanced economies. Khemraj and Pasha (2009) employ fixed effect model and found that real effective exchange rate has a significant positive impact on NPLs for small, medium and large banks in Guyana. In a more detailed study, Raluca and Oaneab (2014) examined the main drivers of stability of commercial and co-operative banks; and if these factors vary among the two 
classes of banks in Romania. The study used Z-score to proxy bank stability index. The authors fitted the macroeconomic variables spanning 2008 to 2012 on simple regression models, one for each class of banks. The results revealed that only GDP growth and interbank rate positively impact on co-operative bank' stability. However, the result could not find any significant factor that could affect the stability of commercial banks among the macroeconomic variables considered. Ekanayake and Azeez (2015) attribute NPLs in Sri Lanka banking system to both macroeconomic conditions and banks' specific factors. They established that NPLs have a positive relationship between loan to asset ratio and prime lending rate, and argued that larger banks incur lesser loan defaults compared to smaller banks.

Some studies attributed varying NPLs drivers across banks to certain factors. According to Detragiache and Gupta (2006), larger banks with cross boarder banking operations could manage systemic crisis better than smaller banks due to easier source of capital in the international financial markets with less severe informational barriers in these markets. Martinez-Miera and Repullo (2010) attributed varying drivers of NPLs across different sizes of banks to factors such as bankcustomer relationships and ownership structure; geographic operational coverage (regional versus national); access to external finance; capital market discipline exposure; and differential regulatory treatment. Since NPLs vary across bank categories, it therefore suggests that drivers of NPL could as well vary across bank type. Recognizing these differences, Bertay et al. (2013) posit that stringent market discipline may be necessary but not expedient for lower categories of banks.

In Nigeria, Akinlo and Mofoluwaso (2014) examine the drivers of NPLs in a macroeconomic model using annual data. The result provides evidence of negative relationship between economic growth and NPLs, while unemployment, credit to the private sector and exchange rate exert positive influence on NPLs. Kanu and Hamilton (2014) investigated macroeconomic determnants of NPLs in two fronts by employing simple OLS regression. The study established inverse relationship between NPLs and GDP in Nigeria. These studies did not consider classification of banks in any form to account for peculiarity of existing banking groups. Similar studies in other climes without recourse to geographical coverage were done 
Non-performing Loan and its Effects on Banking Stability: Evidence from National and International Licensed Banks in Nigeria

by Curak, Pepur and Poposki (2013), Nkusu (2011), Messai and Jouini (2013), Škarica (2014) and Vasiliki et al. (2014).

On the effects of NPLs shocks on banking system stability, contemporary empirical evidences are evidently unavailable in Nigeria, especially with respect to different bank categories or sizes. Kolapo et al. (2012) use a sample of five commercial banks to examine the effect of credit risk on the performance of commercial banks in Nigeria. The results show that the effect of credit risk on bank performance is cross-sectional invariant. Onwe (2015) investigates the relationship between liquidation and banking industry stability in Nigeria. The study used transformed Pearson correlation coefficient to separately determine the effect of bank failure and NPLs on the banking system stability. A long run relationship between bank failure and stability of banking industry was established.

In other jurisdictions, the response of banking stability to NPLs across bank size is mixed. Boyd and Prescott (1986) posit that larger banks could reduce NPLs portfolio by diversifying loan portfolio risks more efficiently than small banks due to higher economies of scale and scope. Boot and Thakor (2000) also argued that larger banks tend to minimize NPLs through better credit administration like credit rationing since fewer credit investments of a higher quality can increase return of the singular investment and hence engenders financial soundness. Beck, et al. (2006) found that large banks can make higher profit, which provide higher capital buffer that mitigates effects of adverse external macroeconomic, NPLs and liquidity shocks, thus reducing the probability of bank crisis. Liu and Wilson (2011) found that banking stability varies across bank types, in that banks with a regional focus are more stable on average than national banks. Laeven et al. (2014) investigated bank systemic risk across large and small banks in 52 countries. Empirical result shows that large banks create more individual and systemic risk than smaller banks, especially when large banks have insufficient capital or unstable funding.

Dayong et al. (2016) conducted a follow up evaluation by examining the impact of NPLs on bank behavior using a threshold panel regression model with dataset 
that covered sixty city commercial banks, sixteen state-owned banks and jointstock banks, and eleven rural commercial banks. The results confirmed the moral hazard hypothesis, which suggests that an increase in the NPLs leads to more lending risk, thus potentially stimulating more poor quality loan and financial system instability.

\subsection{Methodology}

To achieve the objectives of this study, the basic properties of the variables are examined through descriptive statistics, correlation and panel unit root test of Levin, Lin and Chu (LLC) (2002); Im, Pesaran and Shin (IPS) (2003); ADFFisher Chi-square, and Philip Peron (PP). The duality of analytical framework for estimating factors that influence NPLs and examining the impulse response of banking stability to shocks from NPLs is utilized. In the spirit of GMM one step technique; and considering the structure of the Nigerian economy, macroeconomic and bank specific variables are regressed on NPLs. ${ }^{3}$ Z-Score is applied to construct an indicator for banks stability to extricate its response to shocks in NPLs in a panel vector autoregressive system.

\subsection{Data Sources and the Selected Variables}

The bank specific panel data for this study, which ranges from 2014:Q2 to 2017:Q2 were extracted from eighteen individual banks statutory returns to the regulatory authorities in Nigeria $\left(\mathrm{CBN}\right.$ and $\left.\mathrm{NDIC}^{4}\right)$ through Financial Analysis System (FinA) platform. The study period was carefully chosen to accommodate the periods the selected banks had consistent bank specific data with uniform reporting year. This was done to ensure a balanced panel data structure and the banks were further categorized into international and national operational authorization. The macroeconomic data were sourced from the CBN statistical bulletin and National Bureau of Statistics (NBS).

\footnotetext{
${ }^{3}$ Threshold Generalized Autoregressive conditional Heteroskedasticity (TGARCH) model with generalized error distribution was employed to generate nominal exchange rate volatility as one of the macroeconomic variables that measures exchange rate risk. As shown in Appendix 1, TGARCH was preferred to Exponential GARCH for modelling exchange rate volatility.

${ }^{4}$ Nigeria Deposit Insurance Corporation
} 
Non-performing Loan and its Effects on Banking Stability: Evidence from National and International Licensed Banks in Nigeria

Consistent with financial theory and empirical findings as well as with peculiarities of the Nigeria economy, the bank specific variables used in the first estimation stage are NPLs, loan growth, lending interest rate, liquidity ratio, loan to deposit ratio and large exposure. These variables are among the policy tool kits that are directly or indirectly under the control of monetary authorities. We examine four critical macroeconomic variables - real GDP growth rate, nominal exchange rate, weighted average lending rate and exchange rate volatility (exchange rate risk)relevant in explaining changes in NPLs. ROA, ROE and standard deviation of ROA are used to construct Z-score (banking system stability index). Studies have demonstrated that Z-score are more efficient proxy for financial stability than individual indicators. The expected direction of relationships (expected sign) between these variables and NPL as well as Z-Score are presented in Appendix 2.

\subsection{Model Specification}

\section{Dynamic Panel Data Model Specification}

The dynamic panel data estimator is preferred to the traditional OLS fixed-effects or random effects as the former is able to handle endogeneity issues or reverse causality problems while the latter is proven inefficient in these areas. In other words, the technique is more robust and efficient in the presence of multicollinearity problem (Arellano and Bover, 1995). The framework incorporates lagged dependent variable among the regressors to account for time persistence in the structure of the dependent variable. Considering a linear dynamic panel specification of the form:

$$
Y_{i, t}=\alpha Y_{i, t-1}+\beta(L) X_{i, t}+\omega_{i}+\varepsilon_{i, t},|\alpha|<1, i=1, \ldots, N, t=1, \ldots, T
$$

The subscripts $i$ and $t$ represent the cross sectional and time dimension of the panel, respectively. $Y_{(i, t)}$ denote the dependent variable, $Y_{(i, t-1)}$ is one period lag of the dependent variable, $\beta(L)$ is the $1 \times k$ lag polynomial vector, $X_{(i, t)}$ is the $k \times 1$ vector of explanatory variables apart from the lag dependent variable. $\omega_{i}$ are the unobserved individual bank specific effects and $\varepsilon_{i, t}$ are the error terms. The $\alpha$ and $\beta$ measure the dynamic effects of the dependent variable and other regressors 
in the polynomial vector, respectively. To avoid the limitation of the baseline model, in terms of correlation between $Y_{(i, t-1)}$ and $\omega_{i}$, the Generalized Method of Moments (GMM) estimation technique proposed is employed. GMM estimation technique requires a transformation of the model into a first difference in order to eliminate individual specific effects $\left(\omega_{i}\right)$ and also ensure an unbiased and consistent parameter estimates. The transformation of equation (1) is specified as:

$$
\Delta Y_{i, t}=\alpha \Delta Y_{i, t-1}+\beta(L) \Delta X_{i, t}+\Delta \varepsilon_{i, t}
$$

The symbol $\Delta$ is a first (forward) difference operator and other subscripts are as earlier defined. The estimation of equation (2) ushers in two levels of biases from lag dependent and exogenous variables. Therefore, in the spirit of Arellano and Bond (1991) one-step GMM framework, the lag dependent and independent variables are determined based on the assumption of independence and homoscedasticity of residuals and consistent parameter estimates. One-step GMM framework is preferred in this study because Judson and Owen (1999) found that the one-step estimator outperforms the two-step estimator. Moreso, the efficiency gain from the two step estimator are insignificant (see Blundell and Bond (1998) and Blundell et al. (2000)).

Hence, in line with one-step dynamic GMM technique and consistent with related studies (see Merkl and Stolz, (2009), Dimitrios, et al. (2010), Dimitrios, et al (2012), Curak, Pepur and Poposki (2013) and Vasiliki, Athanasios and Athanasios (2014)), the baseline model for this study is formalized, using the selected macroeconomic instruments, as:

$$
\begin{gathered}
\Delta N P L R_{i, t}^{l}=\alpha \Delta N P L R_{i, t-1}^{l}+\beta_{1, k}^{l} \Delta R G D P_{t}+\beta_{2, k}^{l} \Delta I N T R_{t}+\beta_{3, k}^{l} \Delta X R V_{t} \\
+\beta_{4, k}^{l} \Delta I E X R_{t}+\Delta \varepsilon_{i, t}^{l}
\end{gathered}
$$

where $\mathrm{i}=1,2, \ldots, 18$ for the banks (cross sectional) and $t=1,2, \ldots, 14$. The superscript $l$, represents category of banks' license.

Standard errors and Sargan test are downward biased when instrument lists are more or equal to cross sectional units (see Dimitrios, et al. (2010)). To account for this limitation, "restricted" GMM technique ${ }^{5}$ is employed where bank specific

\footnotetext{
${ }^{5}$ See Judson and Owen (1999) for similar application.
} 
Non-performing Loan and its Effects on Banking Stability: Evidence from National and International Licensed Banks in Nigeria

variables are added to the baseline model, one at a time, represented in the form:

$$
\begin{gathered}
\Delta N P L R_{i, t}^{l}=\alpha \Delta N P L R_{i, t-1}^{l}+\beta_{1, k}^{l} \Delta R G D P_{t}+\beta_{2, k}^{l} \Delta I N T R_{t}+\beta_{3, k}^{l} \Delta X R V_{t} \\
+\beta_{4, k}^{l} \Delta I E X R_{t}+\beta_{4, k}^{l} \mathbb{X}_{i, t-k}^{l}+\Delta \varepsilon_{i, t}^{l}
\end{gathered}
$$

where $\mathbb{X}_{i, t-k}^{l}$ represents $i^{t} h$ cross sectional bank specific variables at time $t$. Other regressors have been defined, and notation details are shown in Appendix 2 with summarized interpretations. The model for each type of banking license is estimated in the dynamic and the overall validity of the instruments is tested for each model using the Sargan specification test proposed by Arellano and Bond (1991) and generalized by Arellano and Bover (1995) and Blundel and Bond (1998).

\section{Z-Score Construction}

$Z$ score measures banking system stability and it is computed with three important soundness indicators: Equity/Assets ratio (R/E), the return on assets (ROA) and the standard deviation of return on assets $(\sigma(R O A))$ - a proxy for return volatility. Impliedly, Z score measures the distance from insolvency (Roy, 1952). As formalized by Mercieca et al., (2007):

$$
Z-\text { score }=\frac{R O A+\frac{E}{A}}{\sigma(R O A)}
$$

Simply put, Z-score shows by how many standard deviations ROA could change to make the banks total assets fall short of its total debts. The popularity of Z-score is derived from the established inverse relationship it has with the probability of insolvency of financial institutions.

\section{Panel Vector Autoregressive Model Specification}

To achieve the second objective of this study, unrestricted VAR is employed to uncover impulse responses arising from the interactions of each category of bank stability and NPLs using the model of the form:

$$
y_{i, t}=B(L) y_{i t}+e_{i, t}
$$

where $y_{i, t}$ represents a $k x 1$ vector including Z-score and NPLs. $e_{i, t}$ are cross-sessional errors at time t. The dynamic relations between Z-score and NPLs are revealed through the impulse response functions (IRFs). 


\subsection{Data Analysis and Results}

\subsection{Descriptive Statistics}

The descriptive information in the upper part of Table 2 is quite revealing. The mean values, which fall within the maximum and minimum values of all variables reveals data consistency. Apart from interbank exchange rate and Z-score, the median values suggest relatively low variability of the data as they are not significantly distinct from the mean values as confirmed by the standard deviation. This level of variability in exchange rate provides justification for examining its second moment relevance in the NPLs model.

Furthermore, the observed values of skewness indicate asymmetric distribution, as none was zero and more positive than negative realizations. Apart from interest rate at the macro and bank specific levels, all other variables are right tailed. Interestingly, only interest rate variables are much closer to normal distribution, with kurtosis value of 3. The distribution of TLG, NPLs, LQR and EXRV are leptokurtic. However, the Jarque-Bera statistics and the corresponding probability values confirmed that only bank specific interest rate seems to be normally distributed.

\subsection{Correlation Coefficients of Variables}

The direction and strength of relationship between NPLs, macroeconomic Variables as well as bank specific variables are presented in lower panel of Table 2 . The correlation coefficients between these variables and NPLs seem to suggest weak associationshig. The correlation coefficients between NPLs and five (5) variables (RGDP, WALR, TLG, LQR and Z-score) indicate negative relationships, while other macroeconomic and bank-specific variables displayed positive relationship with NPLs. Correlation coefficients of all the variables with respect to NPLs are significant at the conventional levels. 

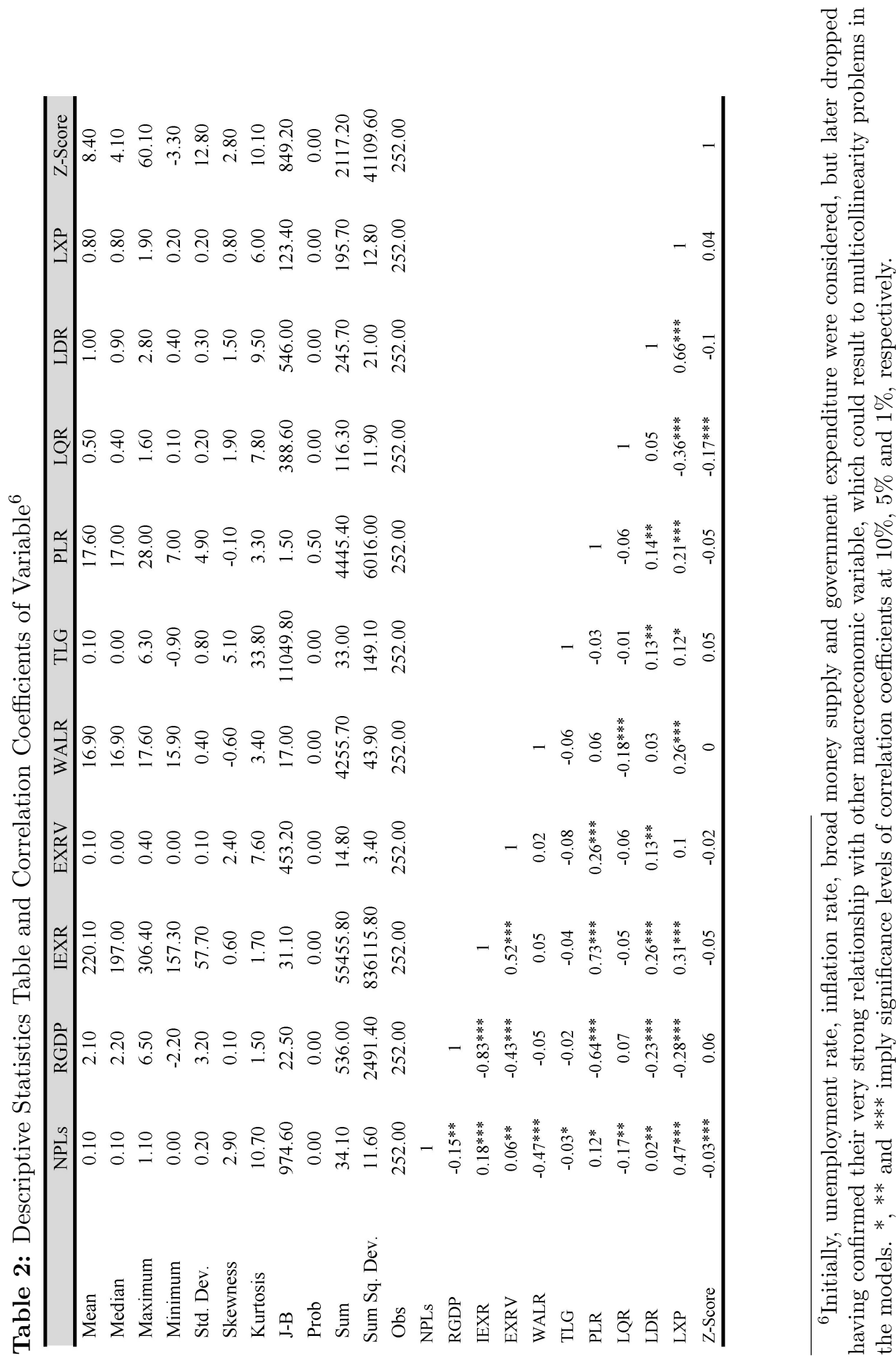
It is important to mention the observed strong positive relationship between prime lending rate and exchange rate movements, although the direction of relationship runs contrary to intuition as negative relationship is expected. Interestingly, the correlation coefficient confirmed weak negative relationship between NPLs and banking stability.

\subsection{Panel Unit Root}

Panel-based unit root tests are found to have higher power than individual time series unit root tests. The null hypothesis of LLC technique assumes common unit root process, while that of IPS, ADF and PP assumes individual unit root process. Among the macroeconomic variables in level form, the null hypotheses of unit root presence cannot be rejected at all conventional significance levels based on the high probability values of test statistics, except LLC for RGDP and WALR (see Table 3).

Table 3: Panel Unit Root Test Results

\begin{tabular}{|c|c|c|c|c|c|c|c|c|}
\hline \multirow{2}{*}{ Variables } & \multicolumn{2}{|c|}{ LLC } & \multicolumn{2}{|c|}{ IPS } & \multicolumn{2}{|c|}{$\mathrm{ADF}$} & \multicolumn{2}{|c|}{ PP } \\
\hline & $\mathrm{t} *$ Stat & Prob & W-stat & Prob & Chi-sq & Prob & Chi-sq & Prob \\
\hline \multicolumn{9}{|c|}{ Macroeconomic } \\
\hline NPLS & 3.41 & 1.00 & 2.28 & 0.99 & 34.62 & 0.53 & 50.34 & 0.06 \\
\hline RGDP & -6.49 & 0.00 & -1.34 & 0.09 & 37.97 & 0.38 & 15.73 & 1.00 \\
\hline WALR & -3.64 & 0.00 & 1.22 & 0.89 & 16.69 & 1.00 & 7.97 & 1.00 \\
\hline EXRV & -0.09 & 0.47 & 5.44 & 1.00 & 3.38 & 1.00 & 0.74 & 1.00 \\
\hline IEXR & -0.32 & 0.37 & 3.16 & 1.00 & 7.48 & 1.00 & 3.65 & 1.00 \\
\hline$\triangle$ NPLS & -2.90 & 0.00 & -5.47 & 0.00 & 102.79 & 0.00 & 162.93 & 0.00 \\
\hline$\triangle \mathrm{RGDP}$ & -9.59 & 0.00 & -7.00 & 0.00 & 114.47 & 0.00 & 97.27 & 0.00 \\
\hline$\triangle \mathrm{EXRV}$ & -10.95 & 0.00 & -4.69 & 0.00 & 77.61 & 0.00 & 272.07 & 0.00 \\
\hline$\triangle \mathrm{IEXR}$ & -9.70 & 0.00 & -4.82 & 0.00 & 83.40 & 0.00 & 71.66 & 0.00 \\
\hline$\triangle \mathrm{WALR}$ & -15.91 & 0.00 & -9.36 & 0.00 & 142.32 & 0.00 & 455.27 & 0.00 \\
\hline \multicolumn{9}{|c|}{ Bank Specific } \\
\hline PLR & 1.01 & 0.84 & -1.72 & 0.04 & 44.73 & 0.02 & 55.61 & 0.00 \\
\hline LQR & -3.46 & 0.00 & -2.40 & 0.01 & 55.84 & 0.02 & 75.08 & 0.00 \\
\hline TLG & -3.25 & 0.00 & -0.61 & 0.27 & 38.42 & 0.36 & 34.07 & 0.56 \\
\hline LDR & -2.25 & 0.01 & -0.80 & 0.21 & 45.19 & 0.14 & 57.43 & 0.01 \\
\hline$\Delta \mathrm{TLG}$ & -6.13 & 0.00 & -4.40 & 0.00 & 79.93 & 0.00 & 131.20 & 0.00 \\
\hline$\Delta \mathrm{PLR}$ & -2.06 & 0.02 & -3.18 & 0.00 & 46.60 & 0.00 & 141.30 & 0.00 \\
\hline$\Delta \mathrm{LRS}$ & -8.12 & 0.00 & -6.43 & 0.00 & 107.73 & 0.00 & 247.62 & 0.00 \\
\hline$\Delta \mathrm{LDR}$ & -4.62 & 0.00 & -3.67 & 0.00 & 73.06 & 0.00 & 186.35 & 0.00 \\
\hline
\end{tabular}

However, a different pattern is observed in terms of stationarity attributes of the 
Non-performing Loan and its Effects on Banking Stability: Evidence from National and International Licensed Banks in Nigeria

bank specific variables in level form. When compared to results for macroeconomic variables, bank-specific variables exhibit equal number of evidence to reject and not to reject the null hypotheses. At first differencing of the bank specific and macroeconomic variables, there is strong evidence, at $1 \%$ level, to reject the null hypotheses of unit root.

\subsection{Pedroni Panel Cointegration}

Pedroni $(1999,2004)$ panel cointegration test, which extended the Engle-Granger (1987) residual-based framework to panel data, is performed to evaluate the null hypothesis of no cointegration of NPLs and macroeconomic variables against homogeneous (within-dimension) and heterogeneous (between-dimension) alternatives. The Pedroni panel cointegration test results for the baseline model are presented Table 4.

Table 4: Pedroni Panel Cointegration Test Results

\begin{tabular}{|c|c|c|c|c|}
\hline \multicolumn{5}{|c|}{ Alternative Hypothesis: Common AR Coefficients. (within-dimension) } \\
\hline & Statistic & Prob. & $\begin{array}{l}\text { Weighted } \\
\text { Statistic }\end{array}$ & Prob. \\
\hline Panel v-Statistic & 0.0066 & 0.4974 & -2.5669 & 0.9949 \\
\hline Panel rho-Statistic & 0.8712 & 0.8082 & 2.1757 & 0.9852 \\
\hline Panel PP-Statistic & -10.1966 & 0.000 & -4.9153 & 0.000 \\
\hline Panel ADF-Statistic & -9.7133 & 0.000 & -4.9727 & 0.000 \\
\hline \multicolumn{5}{|c|}{ Alternative Hypothesis: Individual AR Coefficients. (between-dimension) } \\
\hline & Statistic & Prob. & & \\
\hline Group rho-Statistic & 3.5392 & 0.9998 & & \\
\hline Group PP-Statistic & -7.7549 & 0.000 & & \\
\hline Group ADF-Statistic & -5.6075 & 0.000 & & \\
\hline
\end{tabular}

Drawing from Panel and Group for PP- and ADF-Statistics, six of the eleven statistics strongly reject the null hypothesis of no cointegration at the most conservative level of one percent (1\%), giving the very small probability values. This, therefore, establishes a long run relationship between the NPLs and macroeconomic variables as formalized in the baseline model. 


\subsection{Panel GMM Estimation of NPLs Determinants}

As shown in Table 5, exchange rate movements and exchange rate risk (measured by conditional variance of exchange rate movements) were found to be significant determinants of NPLs of the entire banks put together (industry), but exchange rate risk rendered NPLs non-responsive to changes in the measure of economic activities (baseline model 1). Thus, baseline model 2 which yielded better results in terms of parameter estimates and overall validity of the instruments employed (Sargan test) is maintained for all other models to examine the impact of prudential tools on NPLs. Estimated parameters of panel model for the industry reveal that macroeconomic and bank specific variables examined are significant determinants of NPLs. The parameter estimate of exchange rate risk confirm risk-return tradeoff of efficient market theory - investment with higher risk leads to more returns, higher propensities for loan repayment and lower probability of loan default.

NPLs of banks with international authorization are not significantly affected by exchange rate risks (baseline model 2). This is not unconnected to market information and hedging opportunities that may be available to these banks in the world of international finance. In addition, banks with international scope may embrace sophisticated risk management frameworks with a more robust internal control system that makes them less vulnerable to shocks. Hence, baseline model 1 , having more valid parameter estimates with more robust overall validity of the instruments, remains the reference specification for estimating the effects of bank specific variables. Macroeconomic variables were found to be significant drivers of NPLs among international licensed banks in all the estimated models, except model 3 where growth in total loans was introduced, which made NPLs non-responsive to changes in macroeconomic variable. The negative impact of real GDP growth on NPLs as revealed in this study is contrary to the findings of Raluca and Oaneab (2014). Furthermore, only prime lending rate among the variables specific to international licensed banks was found to be significant determinant of NPLs. 


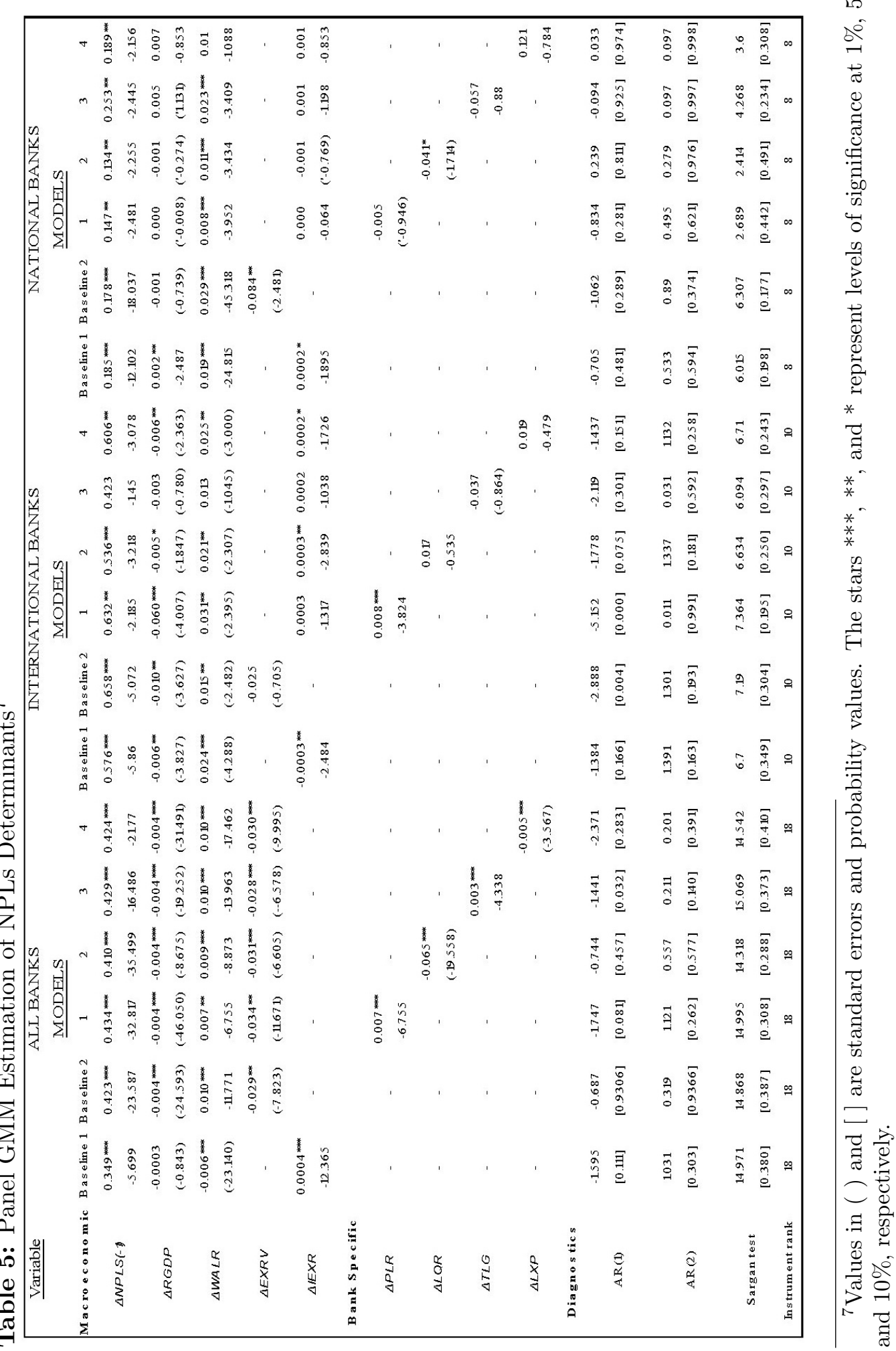


The estimated models for banks with national authorization show interesting results. Exchange rate movements and exchange rate risks are found to affect NPLs. Again, the risk-return tradeoff of efficient market theory is confirmed with the significance of exchange rate risk. However, exchange rate movements suppressed the relevance of RGDP in baseline model 2. Understandably, the opportunities amenable to international banks are not easily accessible to these banks to adequately hedge against exchange rate movement or risk. The international banks sometimes serve as proxy for the national licensed banks when the need arises but such arrangements are done with some caution due to the information that could trigger takeover, hence the outcomes are not usually profitable or beneficial to the lower authorized banks.

Baseline model 1 with better parameter estimates and instrument validity is therefore considered as benchmark model for determining the significance of bank specific variables. Interestingly, the dynamic parameter and industry lending rate were the significant macroeconomic variables, except for model 4 where lending rate turned insignificant. However, industry lending rate conforms to the a priori expectation, which is consistent with the findings of Boyd and De Nicolo (2005) that low lending rates reduces borrowing costs and leads to an increase in entrepreneurial investments in the economy with resulting decline in loan default rates. At $10 \%$ level, liquidity ratio was found to be the only significant variable with the expected a priori among the bank specific variables that could affect NPLs of national banks.

It is important to note the tendency for NPLs to persist as confirmed by the significance of one period lag of NPLs in all the estimated models, confirming the moral hazard hypothesis that an increase in the NPLs ratio raises riskier lending, potentially leading to more toxic assets and financial instability as documented in Dayong et al. (2016). 


\subsection{Response of Banking Stability to Shocks from NPLs}

Table 6 presents the information criteria for selecting optimum lag length for estimating panel vector autoregressive distributed model. Details on these criteria are well documented in Lütkepohl (1991).

Table 6: Panel VAR Lag Order Selection

\begin{tabular}{c|cc|cc|cc|cc|cc}
\hline \multirow{2}{*}{ Banks } & \multicolumn{2}{|c|}{ LR } & \multicolumn{2}{c|}{ FPE } & \multicolumn{2}{c|}{ AIC } & \multicolumn{2}{c|}{ SC } & \multicolumn{2}{c}{ HQ } \\
\cline { 2 - 11 } & Lag & Value & Lag & Value & Lag & Value & Lag & Value & Lag & Value \\
\hline \hline All Banks & 5 & 11.469 & 12 & 0.011 & 12 & 0.507 & 5 & 2.248 & 12 & 1.274 \\
International Banks & 3 & 13.523 & 3 & 0.025 & 5 & 1.997 & 3 & 2.489 & 3 & 2.192 \\
National Banks & 7 & 9.899 & 7 & 0.022 & 7 & 1.824 & 2 & 2.397 & 2 & 2.155 \\
\hline
\end{tabular}

Clearly, two popular information criteria, AIC and SC, yielded conflicting lag lengths. However, Tarun, Asani and Avanidhar (2003) had argued that in this situation, the choice of smaller lag lengths is justified given that the gradient of the information criterion is quite flat for larger lag lengths. On the strength of this argument and in the spirit of parsimony, lag order 5, 3 and 2 are chosen for estimating our panel VAR model for all, international and national banks, respectively.

The estimated panel VAR models for different categories of banks are shown in Appendix 3. Statistical significant parameters at different levels are indicated with number of asterix. As earlier stated, this section of analysis is restricted to impulse response of banking stability to NPLs obtained from panel VAR impulse response function (IRF). Thus, less importance is attached to interpretation of the parameter estimates in this table. However, the stability of the estimated VAR model is a precondition for generating reliable IRF.

Figure 1 displays inverse roots of autoregressive (AR) characteristics polynomial, which depicts the stability of the estimated panel VAR models. Obviously, the graphs confirm the stability or stationarity of the models as all AR roots lie inside the unit circle, giving credence for generating their respective IRFs. 


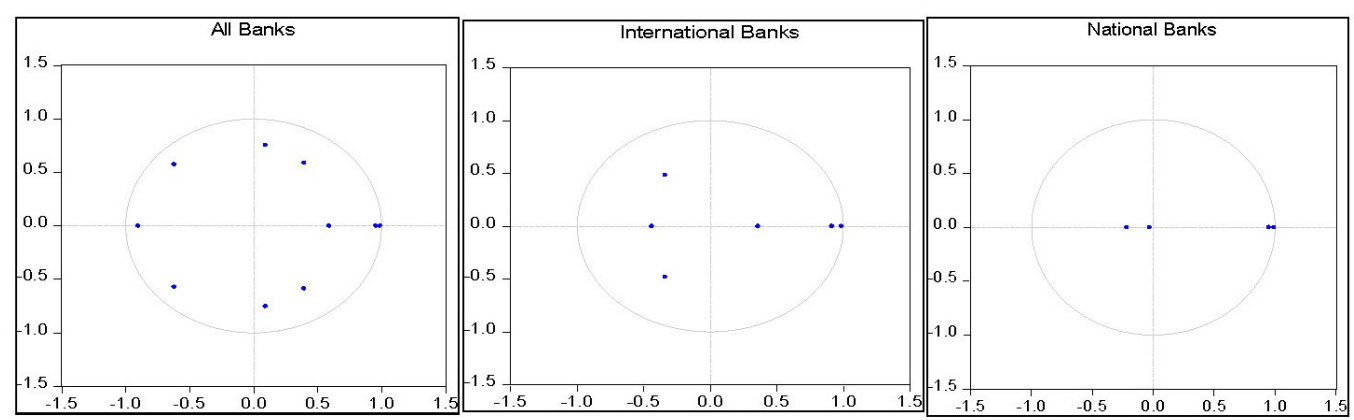

Figure 1: VAR Model Stability Test: Inverse Root of AR Characteristic

Polynomial

Since our interest focusses on extricating banking stability response to shocks in NPLs in various categories of banks, then the responses of NPLs and banking stability to their own shocks as well as responses of NPLs to shocks in banking stability are eliminated. Thus, the only relevant IRFs are presented in Figure 2, which trace the effect of a one-time shock to NPLs innovations on current and future behaviour of baking stability.
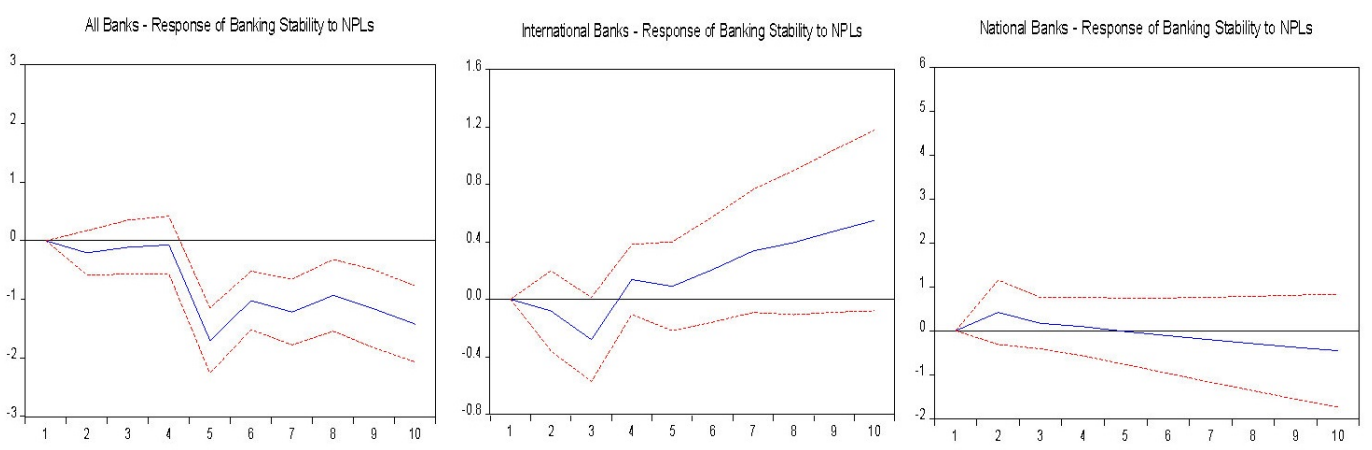

Figure 2: Response to Cholesky One S.D. Innovations \pm 2 S.E.

The impulse response of banking stability is examined up to tenth quarter ahead. As clearly observed with the industry (all banks), the central line of $95 \%$ confidence level in Figure 2 lies below the horizontal line throughout. This implies that banking stability responds negatively to one standard deviation shock in NPLs throughout the horizon, which has significant implication for regulatory authorities. At earlier period, up to fourth quarter, one standard deviation (SD) shock 
Non-performing Loan and its Effects on Banking Stability: Evidence from National and International Licensed Banks in Nigeria

in NPLs had little impact on banking stability, but beyond the fourth quarter, the banking stability response to one SD shock in NPLs became excessively pronounced and highly significant. This suggests that while the industry stability may not be threatened by impulses from NPLs in the short run, the consequences could be devastating in the long run. Therefore, banks' regulatory authority should focus on the appropriate regulatory tools such as the significant drivers of NPLs earlier examined in the dynamic panel structure with the view to using these tools to keep the trend in NPLs on the desired path, especially in the long run.

On the other hand, response of banking stability to one SD shock in NPLs was negative up to fourth quarter and highly significant in quarter three for banks with international operational license. The innovation from NPLs has speedy impact on the stability of this category of banks in the short run, which should be factored into off-site regulatory template to ensure that the banks stay above the turbulent waters of NPLs. Interestingly, beyond quarter four, the response turned positive in the long run. Impliedly, NPLs impulses have symmetric impact on the stability of international banks in the short run and long run.

The impulse response function obtained from national banks reveals a seemingly mirror image of the international bank stability to one standard deviation shocks in NPLs. The stability of banks with national operational license responds positively to one standard deviation shock in NPLs during the first four quarters, but entered negative region in the long run. This is quite revealing. In effect, while the stability of international banks responds negatively in the short run and positively in the long run to shocks in NPLs, the reverse is the case for stability of national banks.

\subsection{Conclusion and Policy Recommendations}

Enthused by the increase in NPLs of banks and its potential threat on financial system stability in the face of uneven recovery from economic slowdown, this study examines the factors driving NPLs and its effects on the stability of international and national banks in Nigeria in a panel framework. The results reveal that drivers of NPLs vary across the two categories. Only exchange rate risk was not significant 
in the determination of NPLs of banks with international authorization, which is not unconnected to market information and hedging opportunities available for these banks; while prime lending rate was found to be the only significant driver of NPLs among the variables specific to international banks. Exchange rate movements and exchange rate risks affect NPLs of banks with national license; whereas liquidity ratio was found to be the only significant variable among the bank specific variables.

All categories of banks confirm the moral hazard hypothesis that an increase in the NPLs ratio raises riskier lending, thereby causing further deterioration of the loan quality and financial system instability. Furthermore, the banking industry and national banks confirm risk-return tradeoff of efficient market theory.

Moreover, international banks were found to withstand shocks from NPLs in the long run, despite observed temporary flux in the short horizon; while the stability of national banks is susceptible to NPLs shocks in the long run. Impliedly, stability of banks with international and national authorization unveiled symmetric response to shocks in NPLs, while the industry portrays asymmetric response.

In terms of policy recommendation, weighted average lending rate, which is anchored on monetary policy rate remains the critical driver of NPLs, therefore, monetary authority should tinker with it to keep the trend in NPLs on the desired path. The outcomes of this study will assist in designing macro-prudential policies in Nigeria. Specifically, banks' regulatory authority should rely more on liquidity ratio for tackling NPLs of national banks. National banks should provide adequate buffers to hedge against exchange rate risk. The speedy impact on the stability of international bank in the short run should be factored into off-site regulatory template to ensure their stability.

In conclusion, apart from bridging the identified gap in literature, the outcome of this research endeavor is a veritable tool for portfolio investment managers to minimize risk and optimize returns; and enhance the regulatory/prudential toolkits of monetary authority in providing: specific supervisory policies for addressing 
Non-performing Loan and its Effects on Banking Stability: Evidence from National and International

Licensed Banks in Nigeria

NPLs; and policy options for mitigating impact of NPLs on the banking system.

\section{References}

Akerlof, G. A (1970). The market for "lemons": Quality uncertainty and the market mechanism. Quarterly Journal of Economics, Vol. 84, No. 3, pp. 488-500

Akinlo, O. and Mofoluwaso, E. (2014). Determinants of non-performing loans in Nigeria. IBFR Accounting and Taxation, Vol. 6, No. 2 pp. 21-28

Altman, E. I. (2000). Predicting financial distress of companies: Revisiting the Z-score and ZETA models. Stern School of Business, New York University, pp. $9-12$

Alton, R.G. and Hazen, J.H. (2001). As economy flounders, do we see a rise in problem loans? Federal Reserve Bank of St. Louis.

Arellano, M. and Bond S. (1991). Some tests of specification for panel data: monte carlo evidence and an application to employment equations. Review of Economic Studies Vol. 58, 277-297.

Arellano, M. and Bover, O. (1995). Another look at the instrumental variable estimation of error-component models. Journal of Econometrics Vol. 68, pp. 29-51.

Arrow, K. J. (1963). Uncertainty and the welfare economics of medical care. The American Economic Review, Vol. 53 No.5, pp. 941-973.

Beck, Thorsten, Asli Demirguc-Kunt, and Ross Levine. (2006) Bank concentration, competition, and crises: first results. Journal of Banking and Finance, Vol. 30 No. 5 pp. 1581-1603

Bertay, A. C. Demirgu c-Kunt, A. and Huizinga, H. (2013). Do we need big banks? Evidence on performance, strategy and market discipline. Journal of Financial Intermediation.

BGL Banking Report (2010). Getting banks to lend again. The banker's magazine of July 2012, Publication of the Financial Times Ltd., London.

Blundell, R., and Bond, S. (1998). Initial conditions and moment conditions in dynamic panel data models. Journal of Econometrics 87, pp. 115-143.

Blundell, R., Bond, S. and Windmeijer F. (2000). Estimation in dynamic panel data models: Improving on the performance of the standard GMM estimator in Baltagi (ed). Advances in Econometrics, Vol. 15: Non-stationary panels, panel cointegration and dynamic panels, JAI Elsevier Science. 
Boot, A.W.A., Thakor, A., 2000. Can relationship lending survive competition? Journal of Finance, Vol 55, pp. 679-713.

Boudebbous, T. and Chichti, J. E. (2013). Determinants of systemic banking crises in the countries of Central and Eastern Europe. Journal of Business Studies Quarterly, Vol 5, No. 1

Boyd, J.H., Prescott, E.C., (1986). Financial intermediary-coalitions. Journal of Economic Theory, Vol. 38, pp. 211-232.

Boyd, J.H. and DeNicol, O, G. (2005). The theory of bank risk-taking and competition revisited. Journal of Finance, Vol. 60, pp. 1329-343.

Skarica Bruna (2014). Determinants of non-performing loans in central and Eastern

European countries. University of Zagreb Working Paper Series 13 - 07.

Caprio, G. and Klingebiel, D. (1999). Episodes of systemic and borderline financial crises, mimeo, World Bank.

Central Bank of Nigeria (2009): Statistical Bulletin, Vol. 20 Central Bank of Nigeria $(2015,2016)$. Financial Stability Report

Central Bank of Nigeria (2016). Understanding monetary policy and financial concepts.

Cottarelli, C., Dell'Ariccia, G., and Vladkova-Hollar, I. (2005). Early birds, late risers, and sleeping beauties: Bank credit growth to the private sector in Central and Eastern Europe and in the Balkans. Journal of Banking and Finance Vol. 29, pp. 83-104.

Curak M., Pepur, S. and Poposki, K. (2013). Determinants of non-performing loans - Evidence from Southeastern European banking systems. Banks and Bank Systems, Vol. 8, No. 1

Dayong Z., Jing C., David G. D., and Ali M. K. (2016). Non-performing loans, moral hazard and regulation of the Chinese commercial banking system. Journal of Banking and Finance, Vol. 63 pp. 48-60

De Bandt O.and Hartmann P. (2000). Systemic risk: A survey. European Central Bank, Working Paper No. 35

Detragiache, E and Gupta, P. (2006): Foreign banks in emerging market crises: Evidence from Malaysia. Journal of financial stability, Vol. 2 pp. 217-242

Dimitrios P. L., Angelos T. V. and Vasilios L. M. (2010). Macroeconomic and bank-specific determinants of non-performing loans in Greece: a comparative study of mortgage, business and consumer loan portfolios. Bank of Greece Working Paper, No. 118 
Non-performing Loan and its Effects on Banking Stability: Evidence from National and International

Dimitrios P. L., Angelos T. V. and Vasilios L. M. (2012). Macroeconomic and bank-specific determinants of non-performing loans in Greece: a comparative study of mortgage, business and consumer loan portfolios. Journal of Banking and Finance, Vol. 36 No.4 pp. 1012-1027

Ekanayake E. and Azeez A.A. (2015). Determinants of nonperforming loans in licensed commercial banks: evidence from Sri Lanka. Asian economic and Financial Review, Vol. 5 No. 6 pp. 868-882

Ezeoha, A. E. (2011). Banking consolidation, credit crisis and asset quality in a fragile banking system. Journal of Financial Regulation and Compliance, Emerald Group Publishing, Vol. 19 No 1, pp. 33-44

European Central Bank (2007). Financial stability review December 2007. https://www.ecb.europa.eu/pub/pdf/other/financialstabilityreview200712en.pdf

Gadanecz, B. and K. Jayaram (2009). Measures of financial stability - a review. IFC Bulletin No 31.

Gorton, G. B. and Pennacchi G. G. (1995). Banks and loan sales: Marketing nonmarketable assets. Journal of Monetary Economics, Vol 35, pp. 389411.

Im, K.S., Pesaran, M.H. and Shin, Y. (2003). Testing for unit roots in heterogeneous panels. Journal of Economics 115, pp. 53-74.

IMF (2012). Bulgaria: 2013 Article IV Consultation". Country Report No.12/328.

Judson, R. A. and Owen, L. A. (1999). Estimating dynamic panel data models: A guide for macroeconomists. Economics Letters, No. 65, pp. 9-15.

Kanu C. and Hamilton I. (2014). The rising incidence of non-performing loans and the nexus of economic performance in Nigeria: An investigation. European Journal of Accounting Auditing and Finance Research, Vol. 2, No.5, pp. $87-96$

Khemraj, T. and Pasha, S. (2009). The determinants of non-performing loans: an econometric case study of Guyana, MPRA Paper 53128, University Library of Munich, Germany

Kolapo, T. F, Ayeni, R. K and Oke, M. O (2012). Credit risk and commercial banks' performance in Nigeria: A panel model approach. Australian Journal of Business and Management Research Vol. 2 No. 2 pp. 31-38

Kraft, E., and Jankov, L., (2005). Does speed kill? Lending booms and their consequences in Croatia. Journal of Banking and Finance Vol. 29, pp. $105-121$ 
Laeven, L Ratnovski, L and Tong H (2014). Bank size and systemic risk. IMF Staff Discussion Note. SDN/14/04

Levin, A., Lin, C. F., and Chu C.S. J. (2002). Unit root tests in panel data: Asymptotic and finite-sample properties. Journal of Econometrics Vol. 108, pp. 1-24.

Liu, H. and Wilson, J. O.S. (2011). Bank type, competition and stability in Japanese banking.

Martinez-Miera, D., and Repullo, R. (2010). Does competition reduce the risk of bank failure? Review of Financial Studies Vol. 23 No. 10, pp. 3638-3664

Mensah F. and Adjei A. (2015): Determinants of non-performing loans in Ghana banking industry. International Journal of Computational Economics and Econometrics, Vol. 5, No. 1.

Mercieca, S., Schaeck, K., and Wolfe, S. (2007). Small European banks: Benefits from diversification? Journal of Banking and Finance, Vol. 31 No. 7

Merkl, C. and Stolz, S. (2009). Banks regulatory buffers, liquidity networks and monetary policy transmission. Applied Economics Vol. 41 pp. 2013-2024

Messai A. S. and Jouini F. (2013). Micro and macro determinants of nonperforming loans. International Journal of Economics and Financial Issues Vol. 3, No. 4 , pp. $852-860$

Musara M. and Olawale F. (2012). Perceptions of start-up small and mediumsized enterprises (SMES) on the importance of business development services providers (bds) on improving access to finance in South Africa. Journal of Social Science, Vol. 30 No. 1 pp. 31-41

Nkusu M. (2011). Nonperforming loans and macrofinancial vulnerabilities in advanced economies. IMF Working Paper, WP/11/161

Onwe B. U. (2015). The relationship between liquidation and banking industry stability in Nigeria. International Journal of Small Business and Entrepreneurship Research Vol.3, No.7, pp.88-99

Padilla A. J. and Pagano M. (2000). Sharing default information as a borrower discipline device. European Economic Review, Vol. 44, Issue 10, 1951-1980

Pagano, M., and Jappelli, T. (1993). Information sharing in credit markets. Journal of Finance Vol. 43 No. 5, pp. 1693-1718

Raluca-Ioana, D. and Oaneab, D. (2014). The main determinants of bank's stability. evidence from Romanian banking sector. Procedia Economics and Finance Vol. 16 pp. 329-335. 
Rothschild, M. and Stiglitz, J. (1976). Equilibrium in competitive insurance markets: An essay on the economics of imperfect information. Quarterly Journal of Economics, Vol. 90, No. 4 pp. 629-649.

Roy, A. D. (1952). Safety first and the holding of assets. Econometrica, Vol. 20, No. 3 pp. 431-449.

Schaeck K., Cihak M., and Wolfe S. (2006). Are more competitive banking systems more stable? IMF Working Paper, WP/06/143. IMF.

Sere-Ejembi, A., Udom, I.S., Salihu, A., Atoi, N.V., and Yaaba, B.N., (2014). Developing banking system stability index for Nigeria. CBN Journal of Applied Statistics, Vol. 5 No. 1.

Stiglitz, J. E. (1990). Peer monitoring and credit markets. The World Bank Economic Review, Vol. 4, No. 3, pp. 351-366.

Tarun C., Asani S., and Avanidhar S. (2003). An empirical analysis of stock and bond market liquidity. Federal Reserve Bank of New York Staff Reports, No. 164.

Vasiliki M., Athanasios T. and Athanasios B. (2014): Determinants of nonperforming loans: the case of eurozone. PANOECONOMICUS, Vol. 2, pp. 193-206.

Warue B. N. (2013): The effects of bank specific and macroeconomic factors on nonperforming loans in commercial banks in Kenya: a comparative panel data analysis. Advances in Management and Applied Economics, Vol.3, No.2 pp. 135-164. 
Appendix 1. Heteroscedasticity Test: ARCH

\begin{tabular}{ccccc}
\hline & F-statistic & Prob. Value & Obs*R-squared & Prob. Chi-Square \\
\hline Pre ARCH Test & 2426.622 & 0 & 175.4774 & 0 \\
Post ARCH Test & 0.008308 & 0.9275 & 0.008398 & 0.927
\end{tabular}

Exchange Rate Volatility Model Selection Criteria

\begin{tabular}{cccc} 
Model & Selection Criteria & Student-t & GED \\
TGARCH & Akaike info criterion & -4.974 & $\mathbf{- 5 . 3 7 3}$ \\
& Schwarz criterion & -4.854 & $\mathbf{- 5 . 2 5 2}$ \\
\multirow{2}{*}{ EGARCH } & Akaike info criterion & -3.961 & -4.847 \\
& Schwarz criterion & -3.841 & -4.727 \\
\hline
\end{tabular}

Appendix 2. Definition of Variables

\begin{tabular}{|c|c|c|c|c|}
\hline \multirow[t]{2}{*}{ Variable } & \multirow[t]{2}{*}{ Notation } & \multirow[t]{2}{*}{ Definition } & \multicolumn{2}{|c|}{ Expected Sign } \\
\hline & & & NPL & Z-Score \\
\hline \multicolumn{5}{|l|}{ Macroeconomic } \\
\hline Real GDP growth Rate & RGDP & $\begin{array}{c}\text { Changes in Economic activities } \\
\text { after accounting for Price } \\
\text { effects }\end{array}$ & $(-)$ & $(+)$ \\
\hline Interbank Exchange Rate & EXR & $\begin{array}{l}\text { Depreciation/Appreciation of } \\
\text { Nigeria Naira to US Dollar } \\
\text { Exchange Rate }\end{array}$ & $(+/-)$ & $(-/+)$ \\
\hline Weighted Average Lending Rate & WALR & $\begin{array}{c}\text { Consolidated weighted average } \\
\text { lending rate of the banking } \\
\text { industry }\end{array}$ & $(+)$ & $(-)$ \\
\hline Exchange Rate Volatility & XRV & Exchange Rate Risk & $(-)$ & $(+)$ \\
\hline \multicolumn{5}{|l|}{ Z-Score } \\
\hline Return on Assets & $\mathrm{ROA}$ & Ratio of Profit to Total Assets & $(-)$ & $(+)$ \\
\hline Equity to Assets & $\mathrm{R} / \mathrm{E}$ & Ratio of Equity to Total Assets & $(-)$ & $(+)$ \\
\hline \multicolumn{5}{|l|}{ Bank Specific } \\
\hline Non-Performing Loans Ratio & NPLs & Ratio of NPLs to Total Loans & & $(-)$ \\
\hline Total Loan Growth & TLG & Changes in Loans over time & $(+)$ & $(-)$ \\
\hline Prime Lending Rate & PLR & $\begin{array}{l}\text { Individual Bank Interest Rate } \\
\text { Charged to Prime Customers }\end{array}$ & $(+)$ & $(-)$ \\
\hline Liquidity Ratio & LQR & $\begin{array}{l}\text { Ratio of Liquid Assets to } \\
\text { Current Liabilities }\end{array}$ & $(-)$ & $(+)$ \\
\hline Loan to Deposit Ratio & LDR & Ratio of Loans to Deposit & $(+)$ & $(-)$ \\
\hline Large Exposure & LXP & $\begin{array}{l}\text { percentage of shareholders } \\
\text { fund unimpaired by losses } \\
\text { granted to clients }\end{array}$ & $(+)$ & $(-)$ \\
\hline
\end{tabular}


Appendix 3. Panel Vector Autoregression Estimates

\begin{tabular}{|c|c|c|c|c|c|c|}
\hline & \multicolumn{2}{|c|}{ ALL BANKS } & \multicolumn{2}{|c|}{ INTERNATIONAL } & \multicolumn{2}{|c|}{ NATIONAL } \\
\hline & Z-Score & NPLS & Z-Score & NPLS & Z-Score & NPLS \\
\hline \multirow{3}{*}{ Z-Score(-1) } & $0.591^{* * *}$ & -0.001 & $0.269 * *$ & 0.001 & 0.934 & -0.0003 \\
\hline & $(-0.067)$ & $(-0.002)$ & $(-0.105)$ & $(-0.005)$ & $(-0.104)$ & $(-0.002)$ \\
\hline & [ 8.884] & {$[-0.533]$} & [ 2.572] & {$[0.255]$} & [ 8.968] & {$[-0.160]$} \\
\hline \multirow{3}{*}{ Z-Score(-2) } & 0.082 & -0.001 & $0.345^{* * *}$ & -0.001 & 0.024 & 0.0001 \\
\hline & $(-0.068)$ & $(-0.002)$ & $(-0.105)$ & $(-0.005)$ & $(-0.103)$ & $(-0.002)$ \\
\hline & [1.203] & {$[-0.456]$} & [ 3.303] & {$[-0.351]$} & {$[0.234]$} & [ 0.065$]$ \\
\hline \multirow{3}{*}{ Z-Score(-3) } & -0.013 & $0.006^{* *}$ & $0.34^{* * *}$ & 0.001 & - & - \\
\hline & $(-0.068)$ & $(-0.002)$ & $(-0.108)$ & $(-0.005)$ & - & - \\
\hline & {$[-0.194]$} & [2.474] & [3.135] & {$[0.15]$} & - & - \\
\hline \multirow{3}{*}{ Z-Score(-4) } & $0.124^{*}$ & $-0.009 * * *$ & - & - & - & - \\
\hline & $(-0.069)$ & $(-0.002)$ & - & - & - & - \\
\hline & [ 1.809$]$ & {$[-3.813]$} & - & - & - & - \\
\hline \multirow{3}{*}{ Z-Score $(-5)$} & $0.165^{* *}$ & $0.005^{* *}$ & - & - & - & - \\
\hline & $(-0.058)$ & $(-0.002)$ & - & - & - & - \\
\hline & [2.875] & [2.642] & - & - & - & - \\
\hline \multirow{3}{*}{ NPLS(-1) } & -2.893 & $0.793 * * *$ & -1.186 & $0.881 * * *$ & 5.98 & $0.766^{* * *}$ \\
\hline & $(-2.618)$ & $(-0.088)$ & $(-2.058)$ & $(-0.102)$ & $(-5.224)$ & $(-0.084)$ \\
\hline & {$[-1.105]$} & [9.030] & {$[-0.576]$} & [ 8.651] & [ 1.145$]$ & [ 9.172] \\
\hline \multirow{3}{*}{ NPLS(-2) } & 2.421 & $0.262 * *$ & -2.772 & 0.179 & -7.74 & $0.221^{* *}$ \\
\hline & $(-3.281)$ & $(-0.11)$ & $(-2.695)$ & $(-0.133)$ & $(-5.362)$ & $(-0.086)$ \\
\hline & {$[0.738]$} & [2.383] & {$[-1.029]$} & [ 1.342$]$ & {$[-1.443]$} & [ 2.567] \\
\hline \multirow{3}{*}{ NPLS(-3) } & 0.83 & -0.13 & $7.132 * * *$ & -0.128 & - & - \\
\hline & $(-3.337)$ & $(-0.112)$ & $(-2.459)$ & $(-0.122)$ & - & - \\
\hline & {$[0.249]$} & {$[-1.161]$} & [2.900] & {$[-1.051]$} & - & - \\
\hline \multirow{3}{*}{ NPLS(-4) } & $-23.549 * * *$ & 0.092 & - & - & - & - \\
\hline & $(-3.804)$ & $(-0.128)$ & - & - & - & - \\
\hline & [-6.191] & {$[0.719]$} & - & - & - & - \\
\hline \multirow{3}{*}{ NPLS(-5) } & $18.638 * * *$ & -0.057 & - & - & - & - \\
\hline & $(-3.425)$ & $(-0.115)$ & - & - & - & - \\
\hline & [5.442] & {$[-0.496]$} & - & - & - & - \\
\hline \multirow{3}{*}{$\mathrm{C}$} & $0.696^{* *}$ & $0.0192 * *$ & -0.104 & 0.015 & 0.618 & 0.015 \\
\hline & $(-0.236)$ & $(-0.008)$ & $(-0.290)$ & $(-0.014)$ & $(-0.649)$ & $(-0.01)$ \\
\hline & [2.953] & [2.424] & {$[-0.357]$} & [ 1.032$]$ & [0.952] & [ 1.483] \\
\hline R-sq & 0.971 & 0.901 & 0.781 & 0.763 & 0.940 & 0.944 \\
\hline Adj.R-sq & 0.97 & 0.895 & 0.768 & 0.749 & 0.937 & 0.942 \\
\hline Schwarz SC & 4.637 & -2.153 & 3.704 & -2.307 & 5.979 & -2.293 \\
\hline
\end{tabular}

